\title{
Evaluation of the Development Characteristics of the 0 to 6 Year Old Children of Families Engaged in Seasonal Agricultural Work
}

\author{
Mevsimlik Tarım İşçisi Ailelerin 0-6 Yaş Çocuklarının Gelişim Özelliklerinin \\ Değerlendirilmesi
}

\begin{abstract}
Aylin DEMİRLI YILDIZ*
Abstract: In this survey of the physical development, nutrition patterns, hygiene and self-care opportunities, potential risks, play and the toys of the children of migrant agricultural workers in Turkey, the data employed was obtained through observation and semi-structured interviews. In this context, the study attempted to analyze in depth the impact of poverty related malnutrition and the unfavourable environmental conditions associated with migration upon the development of children. Firstly, observations on the camp sites of migrant workers, their overall life situations, the major patterns of life in tents and the difficulties faced are briefly given. Secondly, this paper records the results obtained from observations and interviews in respect to the physical development status, the patterns of nutrition, hygiene and self-care, the potential risks, health conditions, play and the toys of these children.
\end{abstract}

Keywords: Seasonal Agricultural Workers, Child, Development

Öz: Türkiye'de gezici mevsimlik tarım işçisi olarak çalışan ailelerin çocuklarının fiziksel gelişimleri, beslenme örüntüleri, hijyen ve öz-bakım olanakları, potansiyel riskler ile oyun ile oyuncaklarının betimlenmesi olarak belirlenmesini amaçlayan araştırmada veriler temel olarak gözlem ve yarı yapılandırılmış görüşmeler yoluyla toplanmıştır. Bu bağlamda yoksulluğa bağlı beslenme yetersizliklerinin yanı sıra göç yaşamının getirdiği uygun olmayan çevresel ortamın çocukların gelişimi üzerindeki etkisi derinlemesine incelenmeye çalışılmıştır. Öncelikle işçilerin yerleşim yerleri, genel yaşam halleri, çadır yaşamının belli başı örüntüleri ve yüz yüze kaldıkları güçlükler gibi çadır grubunun özelliklerine ilişkin gözlemlere kısaca değinilmiş; ardından, çocukların fiziksel gelişimleri, beslenme örüntüleri, hijyen ve öz bakım koşulları, potansiyel riskler ve sağlık koşulları ile oyun ve oyuncak bağlamında gerçekleştirilen gözlem ve görüşmeler sonucu elde edilen izlenimler paylaşılmıştır.

Anahtar sözcükler: Mevsimlik Tarım İşçisi, Çocuk, Gelişim

Today, in any region where labour-intensive agricultural activities take place one can observe seasonal migrant-temporary agricultural labour and workers living in their tent camps established in open spaces. This phenomenon of seasonal agricultural labour that forms these widely observable tent groups can be traced back to the 1950's. Beginning from the 1950's, with the rapid mechanization in agriculture, the fall in agricultural employment and the emergence of an idle labour force in rural settlements (Toprak 1988; Tekeli \& İlkin 1988; Ecevit 1999) resulting in the rural population's rupture from the land and turning them into wage labourers (Boratav 1981). Rural people who were unable to find any jobs in their areas or

\footnotetext{
* Assist. Prof., Başkent University, Faculty of Education, Department of Educational Sciences Psychological Counseling and Guidance Program, Ankara. aydemirli@yahoo.com
} 
in their original settlements began to move to other regions where labour-intensive farming practices prevailed, and this seasonal migration reached significant dimensions over the course of time (Şeker 1986; Aruoba 1988). While remaining a longstanding serious problem, this form of employment assumed a chronic character with the State policies in the 1990's entailing the forced displacement of rural people and the severance of the ties of rural people with their villages.

Although it is a widespread and chronic problem with its origins in the past, reliable and sound information and data even on such basics as the number of seasonally migrating families, their migration routes and socio-demographic characteristics are unavailable today. Nevertheless, recent academic theses and surveys provide some partial information concerning the living conditions of these families and also increased the national visibility of this issue (Çetinkaya 2008). Still, there remains the lack of any substantial information on various aspects of the issue. These issues include the occupational diseases that agricultural workers contract as a consequence of their living conditions, the physiological and psychological effects of exposure to pesticides, the difficulties that women in particular experience and life situations of the children of seasonal agricultural workers (Çetinkaya 2008). This deficiency is so great that there is almost no information available concerning the living conditions, the development and education status, the risks, and the daily routines of children who live and even work with their families in these same environments and conditions. Yet, the most critical period in human development is during the course of the first 5-6 years of childhood. The nature and the quality of the relationship established in this period with the mother or with another caregiver is decisive for the child's mental and behavioural development and for his/her cognition of self and of others (Harel, Oppenheim, Tirosh \& Gini 1999).

There are some studies in the international literature that directly address this issue. These studies have found that children who stay in containers and tents together with their families throughout the period of 7-8 months of migration are exposed to deprivation (Ciesielski, Handzel \& Sobsey 1991; Ciesielski, Loomis, Mims \& Auer 1994) and associated unfavourable circumstances in terms of dress, nutrition and play (Martin \& Kupersmidt 1992); both children and adults are exposed to agricultural chemicals and they have to cope up with ever worsening health conditions and impairment to development (Ciesielski, Handzel \& Auer 1991; Palerm 1992; Ciesielski, Loomis, Mims \& Sobsey 1994). These studies also state that children of agricultural workers experience chronic illnesses more than their peers, while at the same time their access to health services is more limited. Mainly as a result of limited access to health care, there is a higher incidence of such problems as upper respiratory tract infections, such as bronchitis, as also: tuberculosis, parasitic diseases, dermatological problems and iron deficiency (Christenson \& Cautley 1986; Guendelman \& Schwalbe 1986; Weathers, Minkovitz, O’Campo, Diener-West 2004; Slesinger, Şimşek, İnakç1, Koruk \& Shermakov 2010). Studies show that these problems are caused and are further aggravated by poor hygiene, poor nutrition and poor care practices. It is stressed in many studies that upon the onset of adolescence these children start facing other problems. These include psychosomatic disorders, depression (Coles 1965), low performance at school (Henggeler \& Tavormina 1978), a lack of self-confidence while in school education and emotional and behavioural problems (Kupersmidt, Martin \& McCarraher 1993).

What then is the situation in Turkey? In fact, it should be stressed that to a certain extent the experience of other countries has relevance for Turkey. Agricultural workers in Turkey mostly settle near to field crop, sometimes in small groups with 3-5 tents and sometimes in larger 
groups of 200-300 tents for several months in a year. They stay in sloth or in the plastic tents that they erect with their own limited means (Özbekmezci \& Sahil 2004; Kaleci 2007), distant from many infrastructure services including electricity, safe water, sanitation amongst other services. These primitive conditions leave them facing fatal risks. It forms a routine part of their life to experience snake and insect bites (Şimşek \& Koruk 2008), to cope with bitter cold in winter and with extreme heat in summer, especially in places such as Adana. Moreover, due to the lack of the means to safely conserve their food, they face malnutrition; while constant exposure to agricultural chemicals brings, in addition to dermatological, both psychiatric and genetic problems (Yalçın 1980; Yurdakul 1982; Erk, Burgut \& Yıldırım 1986; Şeker 1986; Karacan 1991; Özbekmezci 2003; Kaleci 2007; Özbek 2007; Çetinkaya 2008).

The working conditions of those agricultural workers originating mainly from the Southeastern region of the country, including in the first place Şanlıurfa (Şimşek 2010) are as difficult as their living conditions (Gülçubuk, Karabıyık \& Tanır 2003; Yıldırak, Gülçubuk, Gün, Olhan \& Kılıç, 2003; Gümüş 2005; Özbek 2007; Çetinkaya 2008). The absence of regulations concerning working conditions and systems, together with the lack of any social security coverage, are the main factors, the result of which is that these workers cannot enjoy some rights taken for granted by other citizens, including job security, occupational health and retirement (Yalçın 1980; Yurdakul 1982; Erk et al. 1986; Şeker 1986; Karacan 1991; Özbekmezci 2003; Özbek 2007; Çetinkaya 2008). Moreover, they are subject to intensive exploitation in terms of their labour, and to social exclusion on the basis of a lack of education, of gender and ethnic identity (Nazik \& Gönen 1993; Kaleci 2007; Özbek 2007; Geçgin 2009).

There is no study of the living conditions and the state of the children of seasonal agricultural workers who remain with and face the same circumstances as their parents. Hence, the objective of this survey was to describe the physical development status, nutritional patterns, hygiene and self care, the potentials risks faced by, and the play/toys of the children of families engaged in seasonal agricultural work.

\section{Method}

For this survey based upon qualitative research techniques, observations were conducted of the living circumstances of 0 to 6 years old children and their families, conducted where they stayed and worked in field crops for wages. Interviews were also conducted with selected parents and with health care workers.

\section{Survey Group}

In the selection of the survey areas, those temporary settlements located on the migration routes of families as identified by Gülçubuk et. al. (2003) and Gümüş (2005) were studied. These areas are given in the table below.

Table 1: Fields and dates of survey and the number of interviews conducted

\begin{tabular}{|l|l|l|l|}
\hline Area & & Time & Number of Interviews \\
\hline Ankara Polatlı & (I) & October 2009 & 14 \\
\hline Adana Karataş & & July 2010 & 24 \\
\hline Yozgat Boğazlayan & & September 2010 & 12 \\
\hline Ankara Polatlı & (II) & October 2010 & 11 \\
\hline Şanlıurfa & (I) & December 2010 & Focus group \\
\hline Şanlıurfa & (II) & February 2011 & Focus group \\
\hline
\end{tabular}


While selecting the areas, in addition to the presence of large groups of workers, the following criteria were observed: regional differences and crop diversity; the involvement of middlemen in the procuring workers; the forms of remuneration and the patterns of temporary settlement (i.e. individually or in clusters). In addition to these, this survey also covered one of the major permanent settlement areas of migrant workers, Şanlıurfa (Gülçubuk 2003) considering that data would be richer if the conditions in the original settlements were observed and were compared to those in camping areas. The last field survey was conducted in Polatli-Ankara (in October 2010) to see the degree of difference brought about through the local government project to improve the living conditions of the migrant workers (The problems of agricultural workers were addressed for the first time in 2010 in a Prime Ministerial circular and local branches of the government were instructed to engage in efforts to improve the living conditions of the migrant workers. On the basis of this circular, The Ministry of Labour and Social Security launched a project to improve the living conditions of agricultural workers with pilot work conducted in the Sarıoba village of Polatl District in Ankara Province).

The first field survey was planned (in October 2009) as pilot work. This survey was conducted in the Yassıhöyük village of Polatlı district (Ankara) with a continental climate where workers gather in the $7^{\text {th }}$ and $8^{\text {th }}$ months of the year for the onion farming. The second survey (July 2010) was in the province of Adana which has long been receiving migrant field workers for a variety of crops including cotton, citrus fruit, ground nuts and tomatoes. Adana is also important in that it has, over the course of years, become the permanent place of settlement for those who originally moved there only for seasonal work. In this province, agricultural workers may find opportunities of employment starting from the second month of the year until seventh and eight months. In both Polatl and Adana workers are recruited through middle man and are paid daily wages.

The province of Yozgat was included to display characteristics different from the other areas, in terms of both the living and the working conditions. The migrant workers in this province mainly work in sugar beet cultivation. Uprooting work begins around late September/early October and may continue until the end of December. Workers display dispersed patterns of settlement around fields of the crop, rather than at specific concentration points. The main reason is that the work of uprooting the sugar beet is undertaken by one or two households on an assignment basis depending upon the size of the plot. There are no middlemen in this system and workers work under an agreement made on the basis of the acreage. Since the work of uprooting is left to the initiative of the households concerned, the working period varies depending upon the labour force that a household can mobilize and number of hours allocated to working during a day.

The reason for including Şanlıurfa in this survey (December 2010; February 2011) is that it was the home province of many of the workers encountered in the course of other field surveys. But this survey was carried out in neighbourhoods rather than in field crops and this provided the opportunity to observe the regular-settled life of migrant workers and to make comparisons.

\section{Data Collection}

The survey data was collected mainly through observations and semi-structured interviews.

Observation: In Polatlı (I) and Adana the survey team shared the same living conditions as migrant workers in their tents, in order to obtain direct observation of their daily routines. In other survey areas, on the other hand, there could only be visits and observations made during interviews, since the tents in these locations were too dispersed. Specific emphasis was given to 
the living conditions of the children, including observations of their play, nutrition patterns, and circumstances in their tents and around the camping areas. There was also video footage obtained.

Observing Games: In order to examine how these children played, the survey team daily used a video camera to record the daily play activities of these children and through this method recorded 32 scenes of children at play. Both these videos and other games that were played but which were only observed without any video being made, were evaluated on the basis of a "play observation form" which included information on the games played by the children, the materials employed during play and on the social interaction that accompanied play.

\section{Semi-structured Interviews}

Semi-structured interviews: Interviews with parents were based upon five items which had the intention of obtaining information concerning the parents' views about the needs of their children and as to whether these needs were being met and their own expectations of their children. Other than the parents, interviews were conducted with health workers in the family health centres of Hayatiharrani and in the Eyyubiye neighbourhoods inhabited mostly by agricultural workers and families, which covered such issues as immunization, environmental risks faced by families, their status in terms of access to health services and their most frequent complaints when they apply to health centres.

\section{Data Analysis}

The data collected on the basis of observations in order to depict the daily living practices of the children of seasonal agricultural workers were transformed into a report, together with the adults' relation concerning their children and their practices in daily life.

\section{Findings}

In this part we shall briefly touch upon observations relating to the characteristics of tent groups including places of camping, their overall life situations, major patterns of living in tent camps and the difficulties faced. Then findings from observations and interviews concerning the physical development status, nutritional patterns, hygiene and self care, potentials risks faced by and play/toys of the children will be shared. Considering major development characteristics, each heading is addressed in respect to the age groups 0-2, 2-4 and 4-6.

\section{Characteristics of the Group Worked on}

Findings related to the characteristics of the population covered in all the earlier surveys conducted in Turkey are similar to the findings of the present survey: The household size is 8-10 on average; the average number of children per family is 5-6 and living spaces in migration consist of rural-like camps composed of tents. There are cases where one can see individual tents scattered around due to the nature of work to be done; however, the workers say that they prefer collective settlements for reasons of safety and mutual assistance.

The tents used consist of a single "room" where all the household items are kept. What families bring with them and keep in their tents depends upon the family size and the specific needs and seasons of migration. In some areas around Adana and Şanlıurfa where there is electricity, although very rare, some households were seen to have their own refrigerators. The immediate surroundings of the tents should also be considered, as such daily tasks as cooking and washing the laundry take place there. Other facilities that can be observed around the tents include bathing places and toilets. In areas where there is no common bathing place or latrine, individual families make their toilets through digging the ground at a certain point and covering 
it with cloth or plastic materials.

In all areas, what is stated as being the most important problem area in all the interviews are the wages. Although it is legally prohibited, the majority of workers state that middlemen take their "commission" out of their wages. They have other complaints as well, including belated remuneration or of wage cuts without any sound reason. The workers say they have no channels to make a legal challenge. The women, adolescents and children continue working as disadvantaged workers without any protection at all.

According to the workers, the most frequently confronted problems while working include physical exhaustion, pain in the waist, sunstroke and fainting. Depending upon the nature of work, there are also cuts in the hands, arms and legs and also fractures. As to any care given in case of any health problem or work accident, this is left to the conscience of the middlemen and employers.

Workers provide many examples of exclusion which they face throughout their working period. These include the local inhabitants' distance and annoyance when they are in the coffee houses or walking through the villages; automatically being associated with local cases of theft or other criminal acts; not being able to benefit from local government services; having to pay higher prices in shopping and even the bans instituted by local authorities to prevent them from working in specific provinces or districts.

They say that all of these difficulties and forms of discrimination are also valid for their children and, as such, the future of their children is shaped through these circumstances.

\section{The Living Conditions and Development Patterns of the Children}

\section{Nutrition}

Of course, for both growth and development, there is the need for an environment in which the child can realize the potential existing within his or her genes. The most important components of such an environment include nutrition, a favourable physical environment and a healthy mother (Hatun 2002). Yet the majority of the children of migrant families face undernourishment and malnutrition and are deprived of the chance of being cared for and controlled by adults in respect to their nutrition.

The malnutrition these children experience impacts upon their development from the prenatal period onwards. As a matter of fact, even young mothers who deliver in hospitals even though not medically controlled in their prenatal periods are deprived of folic acid and the supplementary diets needed during pregnancy. Infants from the age of 0 to 2 years are breastfed as long as they can take it and, if the mother has poor lactation, they are given complementary food. It is observed that some families bring their goats or sheep with them and they give yogurt and ayran made from the milk to their children. After the breastfeeding period, children are fed with bulgur (ground wheat) and macaroni, which also form the major food items for their parents.

While the children in the age group 0-2 are given priority in feeding, in as far as available means allow, others in the age groups 2-4 and 4-6 are disadvantaged in the sense that they can have milk and meat products only from what remains after their younger siblings. Starting from the age of 2, the most important item that is missing in the nutritional patterns of children is milk and milk products, as the major source of protein. It is stated that meat consumption remains extremely limited due to economic constraints. A typical diet for these families consists of carbohydrate rich food such as home-made bread, home-made or market macaroni and 
ground wheat dishes accompanied by, depending upon the region concerned, vegetables including onion, eggplant, pumpkin and potato, fried either alone or with the addition of some other ingredients. Tea accompanies all meals. Due to limited means of shopping once settled near the field crops, the lack of means to conserve food and high prices, families say they cannot have vegetables and fruit. Especially after the age of 5, children can have, while their mothers are out working in fields, dishes which were cooked a day earlier, if they have not spoilt due to the hot weather, and they also feed their younger siblings with these. If there is no prepared meal, they just consume plain bread accompanied by tomato, cucumber or slices of water melon. Consequently the relatively older children have no regular and nutritionally proper diet and, as they also carry the responsibility for the feeding their younger siblings, it can be understood that child nutrition is extremely problematic for all age groups.

\section{Physical Development}

It is well established that in addition to malnutrition deriving from poverty, unfavourable environmental circumstances associated with migration lead to poor physical development (Mobed, Gold \& Schenker 1992; Hatun 2002). In order to safeguard them from various risks in the environment, mothers carry their infants under the age of 1 around with them and keep them still while they do something or chat with their neighbours. Without any toy or object in their hand, it can be said that these infants suffer retardation in the development of their larger and smaller muscles relative to their peers and this muscular development can gain pace only after they enjoy some autonomy when they start to walk. This is confirmed by observing 2 years old children walking rather safely and skilfully even over extremely rugged places. Though not at the same level, it can be assumed that this situation may accelerate the development of the smaller muscles as well. After starting to walk, children get the chance of reaching out and grabbing hold of different objects.

Although not as strictly as with their infants, these mothers also try to be close to their 2 to 3 year old children to keep them safe from risks in the environment. While their mothers are nearby the children take, grab, and play with small kitchen items, stones, etc. using their smaller muscles and move around the tents without departing much from their mothers. Two to three years old children can reach out to objects at some distance, run without falling, serve themselves water with glasses and play ball.

As for the self-sufficient children of the age group 4-6 who seem "already grown up as children", it is observed that they have acquired some advanced skills, mainly due to their living conditions. For instance, they can dress without help; undertake such tasks as laundry and dish washing, using big knives quickly and skilfully in slicing melon etc. Towards age 6, they start taking care of their younger siblings. They can dress them, feed them and carry them to places where they should be. Their motor skills are developed enough to do all these and also other things such as cooking. It is hard to think that the many things they are able to do can also be done by their urban middle class peers. It is disputable, however, if these children capable of doing such things including the skilful use of knife would show the same skills if given a paper and pencil. Of all fields that were visited in the survey, in only one tent did the survey team find a child with a drawing book.

\section{Conditions of Hygiene and Self Care}

As is the case in the areas of nutrition and physical development, in the field of hygiene too mothers try to take care of and protect their children, giving priority to the newborn and to infants, as far as their conditions permit. However, as a result of the large number of children 
and the frequency of births, work burden upon the women and the material constraints, the selfcare skills that are considered normal developmental skills of children in urban conditions are largely neglected in life in and around the tents. Indeed, skills and routines such as washing the hands and face, toilet hygiene, brushing the teeth etc. are almost entirely absent.

Diapers are used for infants mostly while they are asleep. While younger mothers tend to use marketed diapers, most mothers use available pieces of cloth, which are washed and reused, and since no other protective material is used children get wet all over. After age 1, diapers are rarely used and smaller children frequently get wet. Thus, mothers try to wash them as frequently as possible. If the climate is fine and water is available mothers give a bath to their smaller children and wash their clothes every day. In other cases, however, when the water supply is limited and it is autumn or winter, this washing takes place only once in three weeks.

Those children with larger and smaller muscle skills developed enough become more autonomous towards the age of 4 , move out of the control of their mothers, and thus try to provide for their self care and hygiene needs on their own. Families take a looser watch over and give less help in such matters as washing and toilet needs as their children get older. In addition to doing these things without any outside help, these children also begin taking care of their younger siblings when they reach the age of 6 .

\section{Potential Risks and Health Conditions}

Interviews with health workers suggest that $70 \%$ of all the applications to health centres by migrant workers are related to the health problems of their children. While these children are not so much retarded in their development, they frequently contract diseases. The physicians interviewed explain this by referring to the following factors: malnutrition associated with poverty; low levels of education and awareness; rare use of soap and water; lack of care and attention by mothers and lack of information on hygiene. As confirmed by the doctors, the dermatological scars around mouths, on the hands and feet are attributable to both malnutrition and poor hygiene.

According to the health workers, the most frequently observed health problems of these children include: fever, asthma and bronchitis in winter and diarrhoeal diseases, parasitic diseases, typhoid fever and brucella giardiasis in summer. Apart from these, the health centres are visited in cases as scorpion stings, dog bites, domestic accidents (especially burns, cuts on body, nail prick, etc). It is also stressed that these families are exposed to heavy chemicals like pesticides, which leads to a high risk of cancer, as well as chronic disorders, dermatological problems and intoxication.

Interviews with mothers and field observations confirmed what health workers related. Many mothers interviewed said they have lost at least one of their children for reasons that can be classified as environmental. Women underline that they are under much more risk while working out in fields than at home. In addition to scorpion, snake and insect bites, having to leave small children alone in the tents and the fact that the elder children work in the fields from time to time bring serious risks which may on occasion prove fatal. They add that even most basic of needs, such as a toilet may turn out to be difficult to meet and the unavailability of safe potable water results in shared health problems.

Adana has an extremely hot climate devoid of any municipal services like the collection of waste or medication against mosquitoe bites. Children also face the risk of falling in or getting drowned in the water canals where they go to obtain some relief from the heat. During the daytime the smaller children have to stay in the tents prone to the greenhouse effect with their 
elders aged 5-6, in extreme heat and humidity which may cause eclampsia in infants and smaller children. As for those tents located close to the main roads, there is the risk of traffic accidents and in fact many injuries occur as a result. In areas like Yozgat and Polatll where the climate is dry and cold, the major health problems are bronchitis and pneumonia. Many children have runny noses. The mothers relate their children frequently become ill and cold which makes it relatively difficult to give them a bath. Still, there are fewer flies and mosquitoes and the dermatological problems are seen less frequently, due to the drier climate and the cool nights. No salient dermatological problem was observed with the exception of some cases of dry skin and insect bites. However, if all the areas are taken together, diarrhoea, burns, insect bites, cuts and injuries from falling are the most commonly observed problems.

In general, the women cook over one fire set near the tents, employing using hay and plastic material collected for this purpose. This way of cooking causes accidents, leading to burns and a dense pungent black smoke from burning this plastic material. While mothers try to protect themselves by covering their noses and mouth, their children are wandering around unprotected.

The child group facing the most serious risks are the children in the group aged 2 to 4 years old, as they are not as closely watched as their younger siblings, while remaining underdeveloped for their own protection. In other words, just by being in the middle, they are neither cared for as closely as their younger siblings, not are they as able to avoid risks as their elders can. It is therefore no coincidence that all children with burns, cuts or thorn pricks were within this age group. Since many of them walk around barefoot, stones or thorns always pose a threat of injury. They are also inclined to pick up the objects they find on ground and put them in their mouth. This carries risks as stockbreeding activities go on around the tents; animal waste is all around. Children in this age group also face other risks while they are out, with cases of a foot being hurt by a hayfork, a tick sticking on the arm or ear, burns after touching the stove or any other hot object, etc.

\section{Play and Toys}

Playing has an important role in learning and cognitive development. The child learns through playing that the realization of any imaginary environment requires the observance of rules. As a socio-cultural activity, play has a role in the development of children's understanding of the world around them, the role of play in the formation of identity (including gender identity) and for their entry into various domains of social life. Theoreticians including Vygotsky, Piaget and Paley underlined the function of play, in addition to that related to their mental development, in consistently placing children's moral and emotional development within the context of group life. They also showed how different forms of playing are both associated with this sociocultural context and assist in its formation (cited by Nicolopoulou, 2004). Through playing, children are prepared for their gender roles and challenging life ahead and internalize group norms and values. It is in this vein that the description of the games played by the children of migrant worker families becomes important

Both videos and direct observations by the field team suggest that the children of couples of relatively younger ages have more toys to play with than the other children. These include: a rocking horse, car and tractor and bicycle and dolls for girls and guns for boys. Other than such objects, from dried out grass in the heat of summer to a frozen pool of water on the ground in winter, anything can form a playing material for children.

Our observations are that mothers keep their children under age 1 very close to them, under one arm or placed on the back, or in a cradle. Their toys are, if they have a chance to reach out, 
objects of their mothers, stones, earth, plants and kitchen utensils dispersed here and there within the tents. When toddling and walking, their toys remain kitchen items, stones, earth, plants and small pieces of wood that they may find while their mothers are close by. If the mother is working out in the fields and the child is just 1-2 years old, he or she is mostly cared by an elder sister if there is one.

Although those children aged between 2-3 years old can move around, they are warned by their mothers and older siblings not to depart too far from the tents. While engaged in the daily household chores, the mothers try to keep them under watch through giving them some objects to play with. One can hardly see any toy in its proper meaning; children use as their "toys" random objects like stones, earth, pieces of wood and any other that can be found near to the tents. Hence, what they find to play with can also include objects such as: large knives, insect deterrent, broken glasses and syringes.

Four to six year old children are relatively more independent. Since they spend longer time out of the tents, almost anything they can find in and around the camping site may be a "toy". In general, children in this age group are freer in their outdoor games and are not much restricted by their families. Without toys, they play games that do not require any. As a matter of fact, games of chasing one another are the most popular of the games.

The six year old group is even more disadvantaged in terms of "routine" toys. This is because, even when they exist, the toys are appropriated by the younger siblings and so the six year olds can play with these toys only to a permitted extent. Female children aged six mostly play -when they are not taking care of their younger siblings- games with action and singing, dininghomemaking games, playing with water, mud, etc. The younger girls usually follow their elder sisters and occasionally participate in their games.

Games involving both girls and boys entail some aggressive acts such as punching and pushing. Nevertheless, it is observed that these acts can become more severe in the games played exclusively by boys. The games played by the male children include: belt hiding, wrestling, jumping down from a hill to the sand, ball games, hide-and-seek etc. For example, in the game "belt hiding" frequently played by male children, a belt is hidden and if the other players cannot find the belt, the hider of the belt has the right to hit them with the belt. The girls, on the other hand, can be said to be more inclined to verbal aggression. Gender based groupings and different groups within each are common. While the relations within a group are alright, there is an aggressive attitude towards other groups. This aggressiveness can be interpreted as a form of adaptation to the harsh environments that these migrant agricultural workers have to cope with. As a matter of fact, these children experience many facts of life, including discrimination from without and domestic violence within. The experience of children with violence in their immediate environments is reflected in their games as aggressiveness.

It is observed that these children of all ages play a kind of 'simulation game' in which they seem to imitate their parents' work, through digging the ground, pressing the soil with their hands and place the earth again from where it was taken. The children also play games that have a kind of creativity, like making cars from bottle lids, or putting plates on head, as if the plates were hats. Apart from all of these, the 'game' that the children like the most is to run after trucks while they are moving and to try to climb up onto them. This quite dangerous act seems to be fun to these children!

To sum up, the games that these children play are of a type that may help them to develop the practical and life skills that are required by their harsh living conditions. In their games, the 
girls prepare for childcare, household works and cooking which they will soon undertake, while the male children prepare for the long hours of work they will undertake in fields of crops at some distance from their tents. However, all of these games remain inherently insufficient when it comes to building the skills essential for school life. Indeed, while their urban middle class peers have Personal Computers at home; enjoy many mental stimulants such as TV, movies, etc and are equipped with the materials needed for cognitive development including story books, drawing pads, etc. the children of these agricultural workers are engaged in games that simply build mechanic and motor skills.

\section{Discussion}

In this survey which aimed at examining life situations of 0 to six year old children of families engaged in seasonal agricultural work, the survey team tried to look "from within" at the living conditions of these workers and their children. When it comes to perceiving the problems of children and the adversities they face, there were times when the members of the survey team referred to their own past experiences and at other times that they referred to what might be considered as an 'ideal' and, many of these points of reference are actually associated with urban middle class practice. In other words, many of the situations and facts that are considered to be 'problematic' by the survey team, are actually regarded as being 'normal' within the context of the living and working practices, and even in the culture of the seasonal agricultural workers who deeply experience poverty, being people regarded simply as a cheap labour force without any social protection and beyond the confines of legislation relating to labour standards.

Any radical change to this situation which has been brought about through poverty and poor living conditions and which is responded to through a kind of "learned helplessness", requires, in addition to improvements in their living conditions and future expectations, also changes to their current perceptions. Such a challenge and change is too broad to be left solely to the efforts of civil society or to experts working in this field.

Given the present situation, any social work can but remain as volunteer efforts merely mitigating some of these problems. The primary prerequisite for sustained solutions is to bring these migrant workers under the umbrella of social protection and to enact specific legislation designed to regulate and civilise their working conditions. It is to be expected that only after these essential steps have been taken that further improvements to the living conditions of these children can take place. Nevertheless, some suggestions can still be made:

1. Though not reaching the desired level, migrant agricultural workers can benefit from services provided by the health centres in the places where they work. However, the newly introduced system of family medicine has its disadvantages for these workers in terms of their access to services. Hence, it is necessary to introduce a system in which workers and their children can benefit from services other than family medicine. Also, the launching of a system of registration may facilitate the monitoring of these workers and their children in matters of health.

2. There is the need for both adult and peer training to improve the information and their awareness concerning matters of hygiene, nutrition and health services. Such training will be more fruitful and women may become more autonomous if leaders among them are trained as trainers and the training is delivered locally. Additionally, there certainly is the need to develop a training content that can be transformed into their native language.

3. Children in the age group 0 to 6 have no preschool education and neither do they have any game or toys that would help to prepare them for formal schooling. After a programme of 
internship and training to be developed under the coordination of the district governorates and the Ministry of Education, students from Faculties of Education must extend education services to these children under the mobile infant school schemes.

4. There is the need to create pressure groups to remind local governments and employers of their serious responsibilities, including the strict control of the use and disposal of chemicals and pesticides and the safe disposal of the residues of chemicals and waste products to prevent any harm to children. Otherwise, these toxic materials will remain within the reach of these children and prove fatal.

In conclusion, agricultural workers are the "bottom" social class in all countries and there are further difficulties in case of migrant agricultural workers. For this reason they are described as a "disadvantaged group" in almost all countries. However, the meaning and the content of being described as "disadvantaged" varies from country to country. For example, studies conducted show that agricultural workers in the U.S.A. mostly live in dwellings with electricity and connected to the water network, $42 \%$ of them have vacuum cleaners, work in conditions that protect them from exposure to chemicals and pesticides and their camping sites are located at a safe distance from the fields of crops (McCauley, Lasarev, Higgins, Rothlein, Muniz, Ebbert \& Phillips 2001). These facilities are well beyond what can be expected by agricultural workers in Turkey. Nevertheless, efforts to improve the working and living conditions of seasonal agricultural workers will have benefits, not only for the workers themselves but also contribute to the healthy development of their children, who experience these same conditions. 


\section{REFERENCES}

Aruoba, Ç. (1988). Tarımda Teknolojinin Değisşimin Gelir Dağılımına Etkisi in Türkiye'de Tarımsal Yapılar. Ankara 1988.

Boratav, K. (1981). Tarımsal Yapılar ve Kapitalizm. Birikim Yayınları, Yerli Araştırmalar Dizisi, Ankara 1981.

Ciesielski S., Handzel T. \& Sobsey M. (1991). "The Microbiologic Quality of Drinking Water in North Carolina Migrant Labor Camps”. American Journal of Public Health 81 (1991) 762-764. doi:10.2105/AJPH.81.6.762.

Ciesielski S., Loomis D. P., Mims S. R. \& Auer A. (1994). "Pesticide Exposures, Cholinesterase Depression, and Symptoms Among North Carolina Migrant Farmworkers". American Journal of Public Health 84 (1994) 446-451. doi:10.2105/AJPH.84.3.446.

Coles R. (1965) “The Lives of Migrant Farmers”. American Journal of Psychiatry 122 (1965) 271-285.

Çetinkaya Ö. (2008) Farm Labor Intermediaries in Seasonal Agricultural Work in Adana-Çukurova. Yayımlanmamış Yüksek Lisans Tezi. ODTÜ Sosyal Bilimleri Enstitüsü. Ankara 2008.

Ecevit M. (1999). Kırsal Türkiye'nin Değişim Dinamikleri: Gökçeağaç Köyü Monografisi. Ankara 1999.

Erk N., Burgut R. \& Yıldırım E. (1986). Çukurova Bölgesine Gelen Geçici Tarım İsçilerinin Çalışma ve Yasam Koşullarının İyileştirilmesi. TÜBİTAK TOAG 519 Projesi.

Geçgin E. (2009). Türkiye'de Mevsimlik Tarım İş̧̧iliğinin Sosyolojik Analizi: Ankara Polatlı Örneği. Yayımlanmamış Yüksek Lisans Tezi. Ankara Üniversitesi, Sosyal Bilimler Enstitüsü. Ankara 2009.

Guendelman S. \& Schwalbe J. (1986). "Medical Care Utilization by Hispanic Children”. Medical Care 24 (1986) 925-940. doi:10.1097/00005650-198610000-00006.

Gülçubuk B., Karabıyık E. \& Tanır F. (2002). "Türkiye Tarım Sektöründe En Kötü Biçimdeki Çocuk İş̧iliği Temel Araştırması (Adana İli-Karataş İlçesinde Pamuk Toplamada Çalışan Çocuklar Örneği)”. Türkçe Basılmamış Araştırma Raporu, Ankara 2002.

Gülçubuk B., Karabıyık E. \& Tanır F. (2003). Baseline Survey on Worst Forms of Child Labour in the Agricultural Sector. Project Report. Ankara 2003.

Gümüş A. (2005). “Çukurova'nın Ötekileri”. Tiroj, Mayıs-Haziran 2005, 22-26.

Harel J., Oppenheim D., Tirosh E. \& Gini M. (1999). “Associations Between Mother-Child Interaction and Children's Later Self and Mother Feature Knowledge”. Mental Health Journal 20/2 (1999) 123137.

Hatun Ş. (2002). Çocuk Hakları Sözleşmesinin 13. Yılında Yoksulluk ve Çocuklar Üzerine Etkileri. Türk Tabipler Birliği, Ankara 2002.

Henggeler S. W. \& Tavormina J. B. (1978). "The children of Mexican-American migrant workers: a population at risk?” Journal of Abnormal Child Psychology 6/1 (1978) 97-106. doi:10.1007/ BF00915785.

Kaleci H. (2007). Mevsimlik Tarım işçilerinin Sosyolojik Analizi: Eskişehir Örneği. Yayımlanmamış Yüksek Lisans Tezi. Anadolu Üniversitesi, Sosyal Bilimler Enstitüsü. Eskişehir 2007.

Karacan A. R. (1991). Tarım Kesiminde Geçici Tarım İsçilerinin Çalışma Koşulları, Ücret Sistemleri ve Çalışanların Sosyal Güvenlikleri Üzerine Bir Arastırma: Manisa Örnegi. İstanbul 1991.

Kupersmidt J. B., Martin S. L. \& McCarraher D. R. (1993). "A Spanish version of the CASA: Issues in Translation for Use with Hispanic Migrant Farm Workers and Preliminary Results of a Study of Service Use in This Population". Proceedings of the Fifth Annual Research Conference on a System of Care for Children's Mental Health: Expanding the Research Base 1 (1993) 81-90.

Martin S. L. \& Kupersmidt J. B. (1992). "Rural Children at Risk: Mental Health Service Utilization Among Children of Migrant and Seasonal Farm Workers”. Outlook 2 (1992) 26-28.

McCauley L. A., Lasarev M. R., Higgins G., Rothlein J., Muniz J., Ebbert C. \& Phillips J. (2001). "Work Characteristics and Pesticide Exposures Among Migrant Agricultural Families: A Community-Based Research Approach”. Environmental Health Perspectives 109/5 (2001) 533-538. doi:10.1289/ ehp.01109533

Mobed K., Gold E. B. \& Schenker M. B. (1992). “Occupational Health Problems Among Migrant And 
Seasonal Farm Workers”. Western Journal of Meicined 157/3 (1992) 367-373.

Nazik H. \& Gönen E. (1993). Kadınların Mevsimlik Tarım İşlerinde Çalışmalarının Ailenin Ekonomik Durumu ve Yasam Biçimine Etkisi, Bilimsel Araştırma ve İncelemeler. A.Ü. Ziraat Fakültesi, Bilimsel Araştırma ve İncelemeler. Ankara 1993.

Nicolopoulou A. (2004). "Oyun, Bilişsel Gelişim ve Toplumsal Dünya: Piaget, Vygotsky ve Sonrası” Çev. M. T. Bağlı. Ankara University Eğitim Bilimleri Fakültesi Dergisi 37/2 (2004) 137-169. Ankara 2007.

Özbek A. (2007). New Actors of New Poverty: The "Other" Children of Çukurova. Unpublished Master Thesis. Ankara: METU Graduated School of Social Sciences.

Özbekmezci Ş. (2003). Mevsimlik Tarım İşçilerinin Barınma Sorunları ve Yaşam Üniteleri. Yayınlanmamış Yüksek Lisans Tezi. Gazi Üniversitesi, Fen Bilimleri Enstitüsü. Ankara 2003.

Özbekmezci Ş. \& Sahil S. (2004). “Mevsimlik Tarım Işçilerinin Sosyal, Ekonomik ve Barınma Sorunlarının Analizi”. Gazi Üniversitesi Mühendislik Mimarlık Fakültesi Dergisi 19/3 (2004) 261-274.

Palerm J. V. (1992). “A Season in the Life of a Migrant Farm Worker in California”. Western Journal of Medicine 157 (1992) 362-366.

Slesinger D. P., Christenson B. A. \& Cautley E. (1986). "Health and Mortality of Migrant Farm Children”. Social Science \& Medicine 23/1 (1986) 65-74. doi: 10,1016/0277-9536(86)90325-4

Şeker M. (1986). Türkiye’de Tarım İşçilerinin Toplumsal Bütünleşmesi. Ankara 1986.

Şimşek Z. \& Koruk I. (2008). "Şanlıurfa İl Merkezinde Gezici Mevsimlik Tarım İşçiliği Durumu ve Sağlık Hizmetine Erişim”. XII. Ulusal Halk Sağlı̆̆ı Kongresi (2008) 22-26 October, Ankara.

Şimşek Z. (2010). "Mevsimlik Göçebe Tarım İşçisi Gençlerin Sağlıklı Yaşam Bilgi ve Davranışlarına Akran Eğitiminin Etkisi”. Ulusal Nüfus Bilim Kongresi. Ankara, October 2010.

Şimşek Z., İnakçı İ. H., Koruk İ., \& Shermakov K. (2010). "Vaccination Status in Children Aged 12-23 Months and Predictors in Şanlıurfa”. Pediatri Dergisi 19/1 (2010) 20-29.

Tekeli İ. \& İlkin S. (1988). “Devletçilik Dönemi Tarım Politikaları”. Türkiye’de Tarımsal Yapılar (19232000). Der. Ş. Pamuk ve Z. Toprak, (1988) 37-89. Ankara.

Toprak Z. (1988). “Türkiye Tarımı ve Yapısal Gelişmeler (1900-1950)”. Türkiye’de Tarımsal Yapılar (1923-2000). Der. Ş. Pamuk ve Z. Toprak, (1988) 19-36. Ankara.

Yalçın Ö. F. (1980) Çukurova Bölgesinde Mevsimlik Tarım İsçilerinin Sosyo-Ekonomik Sorunları Üzerinde Bir Araştırma. A.Ü. Ziraat Fakültesi, Yayınlanmamış Doktora Tezi. Adana 1980.

Yıldırak N., Gülçubuk B., Gün S., Olhan E. \& Kılıç M. (2003). Türkiye’de Gezici ve Geçici Kadın Tarım Iş̧̧ilerinin Çallşma ve Yaşam Koşulları ve Sorunları. Ankara 2003.

Yurdakul N. (1982) Adana İlinde Geçici Tarım İsçilerinin Sosyo-Ekonomik Sorunları. Ankara 1982.

Weathers A., Minkovitz C., O’Compo P. \& Diener-West M. (2004). “Access to Care for Children of Migratory Agricultural Workers: Factors Associated With Unmet Need for Medical Care”. Pediatrics 113/4 (2004) 376-385. doi:10.1542/peds.113.4.e276. 